\title{
Література
}

1. Браже Т. Г. Развитие творческого потенциала учителя / Т. Г. Браже // Советская педагогика. 1989. - № 8. - С. 85-94. 2. Вишнякова Н. Ф. Креативная акмеология. Психология высшего образования : [монография] : в 2-х т. / Н. Ф. Вишнякова. - Т. 2. Прикладная акмеология. - [2-е изд.]. Мн. : ООО «Дэбор», 1999. - 300 с. З. Закон України «Про освіту». - К. : Инза, 1996. - 36 с. 4. Кичук Н. В. Формування творчої особистості вчителя / Н. В. Кичук. - К. : Либідь, 1991. - 96 с. 5. Семиченко В. А. Теоретичні та методичні основи професійного самовиховання студентів вузу : [навч.метод. посіб.] / В. А. Семиченко, О. М. Галус, Л. В. Задневич. - Хмельницький : ХГПИ, 2001. - 255 с.

Марія Кислова

\section{ПРОБЛЕМИ КОМПЕТЕНТНІСНОГО ПІДХОДУ В ІНЖЕНЕРНІЙ ОСВІТІ}

Кислова М. А. Проблеми компетентністного підходу в інженерній освіті.

У статті розглянуто проблеми, які виникають у процесі навчання вищої математики студентів інженерних факультетів, розкрито зміст поняття математичної компетентності, досліджено три основні напрямки вдосконалення освітнього процесу.

Ключові слова: компетентність, компетенція, освітній процес, засоби навчання математики, інформаційно-комунікаційні технології (ІКТ).

Кислова М. А. Проблемы компетентностного подхода в инженерном образовании.

В статье рассмотрены проблемы, которые возникают при обучении высшей математике студентов инженерных факультетов, раскрыто содержание понятия математической компетентности, исследованы три основне направления усовершенствования образовательного процесса.

Ключевые слова: компетентность, компетенция, образовательный процесс, средства обучения математике, информационно-коммуникационные технологии (ИКТ).

Kislova M. A. Problems competense the approach in engineering education.

In article problems which arise at training to higher mathematics of students of engineering faculties are considered, the concept of mathematical competence is expanded, investigated three directions of improvement of educational process.

Key words: competence, the competence, educational process, tutorials to the mathematician, information-communication technologies (ICT).

Інноваційний шлях розвитку української економіки вимагає забезпечення інженерними кадрами, здатними розв'язувати принципово інші, ніж раніше, задачі, зумовлені новими технологічними укладами, інформаційним суспільством, інноваційними формами економічної діяльності. Для цього студенти інженерних (технічних) ВНЗ повинні отримати освіту, що враховує нові реалії та перспективи розвитку суспільства, яка дозволить їм бути конкурентоспроможними, мобільними, готовими до адаптації й саморозвитку [5].

Підвищення якості освіти означає розв'язання пріоритетних задач, серед яких забезпечення інноваційного характеру базової освіти, реалізації компетентнісного підходу, взаємозв'язку академічних знань і практичних умінь.

Визначаючи сучасні цілі та результати професійної освіти, дослідники розглядають в єдності систему якостей особистості випускника ВНЗ, що забезпечують здатність і готовність успішно здійснювати професійну діяльність. Така система когнітивних, мотиваційних, діяльнісних, рефлексивних якостей особистості інтегрує поняття компетентності. У компетентнісному підході професійна компетентність визначає якість професійної освіти і $є$ ії метою.

Компетентнісний підхід розглядається в роботах таких дослідників: В. Адольф, С. Архангельский, Ю. Бабанський, В. Беспалько, В. Давидов, І. Ісаєв, Н. Тарасова [2] як інноваційний і продуктивний. Разом з тим його реалізація в інженерних ВН3, порівняно 3 іншими категоріями ВНЗ, становить складну науково-методичну задачу, оскільки інженерна освіта, що забезпечує кадрами реальний сектор економіки, $є$ найбільш наукомісткою 3 усіх галузей освіти, по-перше, тому, що досліджувані предмети складні для засвоєння; по-друге, 
темп відновлення знань $є$ найбільшим саме в техніці й технології. Урахування зазначеної специфіки інженерної освіти визначає вимоги до викладання фундаментальних дисциплін в інженерному ВН3, зокрема дисциплін математичного циклу. Стрімкий розвиток комп'ютерної техніки й інформаційно-комунікаційних технологій (IКТ), по-перше, дозволив підвищити ефективність математичних методів в інженерних розрахунках і дозволив здійснювати математичне та комп'ютерне моделювання складних процесів, нових матеріалів, техніки і технологій, по-друге, актуалізував формування математичної компетентності випускника інженерного ВНЗ, яка в цих умовах стає базовим складником професійної компетентності.

У дослідженнях, проведених за останні 30 років із теорії та методики навчання математики в ВНЗ у контексті підвищення якості, можна виокремити три основні напрямки, у яких здійснюється вдосконалення освітнього процесу: через професійно-спрямоване (контекстне) навчання; використання міжпредметних зв'язків; застосування комп'ютерної техніки. Кожен із цих напрямків спирається на певний методологічний базис і розглядає його як провідний.

У межах першого напрямку найбільш повно досліджено професійно спрямоване навчання математики майбутніх учителів математики в педагогічному ВНЗ (М. Жалдак, Н. Морзе, С. Раков, Л. Шкеріна та ін.) [1]. Значною мірою це навчання досліджено стосовно економічних ВНЗ (В. Биков, Л. Білоусова, Т. Добудько, М. Жалдак, Е. Кузнєцов, О. Кузнєцов, М. Лапчик, С. А. Рако, Ю. Рамський та інші).

Різні аспекти методики професійно спрямованого навчання математики було розроблено для інженерних спеціальностей (Л. Гусак, І. Коновалова, А. Кудрявцев, В. Швець).

За цей період створено психолого-педагогічну теорію контекстного навчання. Доведено, що контекстне навчання реалізує особистністно зорієнтований і компетентнісний підходи (К. Альбуханова-Славська, М. Данилов, О. Ковальов, С. Рубінштейн, Ю. Фролов [3]). Однак положення теорії контекстного навчання математики в інженерному ВНЗ слід розвинути і конкретизувати. Так, не розробленими $є$ система відбору змісту контекстного навчання математики в інженерному ВНЗ, методологія проектування засобів навчання математики 3 позицій державних освітніх стандартів для різних інженерних напрямків, не вивчено вплив контекстного навчання на якість фундаментальних математичних знань.

У межах другого напрямку досліджень теорія міжпредметних зв'язків у ВНЗ розроблена недостатньо. Міжпредметні зв'язки вивчалися переважно з позицій навчального підходу, наприклад, їх роль у формуванні математичної компетентності студентів розкрито негрунтовно, вимагає уточнення і саме поняття міжпредметних зв'язків.

Третій напрямок, пов'язаний із застосуванням у навчанні математики обчислювальної техніки (предметно-інформаційний підхід), перебував у полі посиленої уваги відомих математиків (В. Арнольд, І. Гельфанд, А. Єршов, Ю. Журавльов, А. Колмогоров, С. Новіков, А. Семенов, С. Соболєв, О. Тихонов та інші), а також фахівців з методики навчання математики та інформатики (Т. Бєлявцева, Л. Білоусова, О. Колгатін, І. Кузнєцова, Ю. Лотюк, Ю. Рамський, С. Семеріков, Т. Степанова, А. Сушенцов, Г. Федченко). Однак розвиток інформаційного суспільства актуалізує нові задачі дослідження. Так, у навчанні математики необхідно формувати готовність студента використовувати ІКТ у процесі математичного моделювання у професійній діяльності, враховуючи при цьому, що ІКТ постійно еволюціонують.

Нині актуальним є ще один напрям досліджень, пов'язаний з фундаменталізацією навчання. В умовах динамічного розвитку суспільства роль фундаменталізації навчання зростає як підхід, спрямований на забезпечення системоутворювальних знань студента, які, будучи основою його професійного розвитку в майбутньому, дозволять розуміти і швидко оволодівати новими технологіями, розуміти принципи роботи i професійні функції. Фундаменталізація навчання математики, забезпечуючи в довгостроковій перспективі здатність і готовність випускника застосовувати у професійній діяльності знання, реалізує потенціал компетентнісного підходу.

Більшість дослідників виокремлюють у структурі компетентності когнітивний, мотиваційноціннісний, діяльнісний і рефлексивно-оцінний компоненти (Н. Бібік, І. Срмаков, О. Овчарук, Л. Паращенко, О. Пометун, О. Савченко, Л. Сохань, С. Трубачова, С. Шишов [4]). Однак формування цих компонентів професійної та математичної компетентності передбачає використання різних підходів у навчанні. Наприклад, для когнітивного компонента основним підходом можна вважати фундаменталізацію, для діяльнісного - контекстний підхід (професійно спрямоване навчання), для мотиваційно-ціннісного - особистісно зорієнтований і контекстний підходи, а 
для рефлексивно-оцінного компонента - особистісно зорієнтований підхід. Отже, інтегративна структура математичної компетентності зумовлює комплексне використання різних підходів у навчанні математики, що забезпечує формування всіх іiі компонентів за провідної ролі компетентнісного підходу, що визначає мету і результати навчання.

Метою статті є дослідження проблем, які виникають у процесі навчання вищої математики студентів інженерних ВНЗ та пов'язані з формуванням математичної компетентності студентів.

Необхідність підвищення якості освіти значно актуалізує теоретичні та методичні проблеми, пов'язані з формуванням математичної компетентності студентів на основі комплексного використання різних підходів у навчанні, що грунтуються на різних освітніх парадигмах. Виникає наукова проблема розроблення теорії і методики навчання математики на основі парадигмального підходу.

На шляху розроблення теорії і методики навчання математики студентів інженерних ВН3 постає проблема у формувані математичної компетентності як базового складника професійної компетентності та в розробленні відповідних методичних моделей навчання математики студентів інженерних ВНЗ. Розв'язання окресленої проблеми надає змогу розв'язати й інші питання, які виникають у процесі навчання вищої математики студентів технічних ВНЗ:

- необхідність практичного використання математичного апарату у професійній діяльності випускниками на основі сформованої компетентності в навчанні математики;

- недостатня розробленість теоретичних і практичних аспектів контекстного навчання математики в інженерному ВНЗ;

- недостатній рівень розробленості міжпредметних зв'язків та методичних аспектів їх формування.

Виявлені проблеми відображають недостатню розробленість компетентністного, контекстного, міжпредметного, предметно-інформаційного підходів у теорії та методиці навчання математики студентів інженерного ВНЗ і зумовлюють необхідність розроблення теоретичних основ і методичної системи, що спираються на поєднання різних парадигм: визначальної компетентнісної, а також знаннєвої, системно-діяльнісної, особистісно зорієнтованої тощо.

Математична компетентність - інтегративна динамічна властивість особистості студента, що характеризує його здатність і готовність використовувати у професійній діяльності методи математичного моделювання. Математична компетентність інтегрує математичні знання, вміння та навички, а також загальнокультурні і професійні компетенції, спроектовані на предметну площину математики - їх ядром є здатність і готовність випускника застосовувати ці знання у професійній діяльності. Формуванню математичної компетентності студентів інженерного ВНЗ сприяє навчання математики на основі парадигмального підходу, у якому інтегруються, комплексно використовуються різні підходи в навчанні.

Розроблення теоретичних основ і методичної системи навчання математики в інженерному ВН3 на основі парадигмального підходу передбачає: уточнення цілей навчання математики та встановлення їх ієрархії; виокремлення основних методичних ліній у навчанні, спрямованих на досягнення приватних цілей, які перебували у формуванні відповідних компонентів математичної компетентності, кожен із яких має когнітивний, мотиваційно-ціннісний, діяльнісний і рефлексивно-оцінний складники; уточнення сутності переходу від знаннєвого навчання математики до компетентнісного і побудова його дидактичного базису, що включає загальнодидактичні принципи, пов'язані 3 формуванням здатності і готовності студента застосовувати знання; обгрунтування використання в межах парадигмального підходу контекстного, міждисциплінарного, предметно-інформаційного підходів, фундаменталізації тощо за провідної ролі компетентнісного підходу; подальший розвиток теорії, пов'язаної з цими підходами, зокрема, в методичному аспекті; розроблення методів оцінки математичної компетентності.

Концепцію навчання дисциплін математичного циклу студентів інженерного ВНЗ на основі парадигмального підходу визначає оптимальне поєднання системного, діяльнісного, особистісно зорієнтованого, міждисциплінарного, контекстного, предметно-інформаційного та компетентнісного підходів і зумовлено цим сукупність специфічних принципів: пролонгованої компетентності, професійного контексту, прикладної значущості, міждисциплінарної інтеграції, математикоінформаційного доповнення, оперативної рефлективності, історичної спадкоємності. Концепція навчання $є$ теоретичною основою для наукового прогнозування та розроблення методичної системи навчання студентів інженерного ВНЗ на основі парадигмального підходу. 


\section{Література}

1. Жалдак М. І. Комп'ютерно-орієнтовані засоби навчання математики, фізики, інформатики / М. І. Жалдак, В. В. Лапінський, М. І. Шут // Інформатика. - 2006. - № 3-4. - С. 3-96. 2. Тарасова Н. В. Стратегия реализации компетентностного похода в образовании: историкопедагогический аспект / Н. В. Тарасова. - М.: ФИРО, 2007. - 52 с. - (Содержание, формы и методы обучения в высшей школе: Аналитические обзоры по основным направлениям развития высшего образования / ФИРО; Вып. 1). 3. Фролов Ю. В. Компетентностная модель как основа оценки качества подготовки специалистов / Ю. В. Фролов, Д. А. Махотин // Высшее образование сегодня. 2004. - №8. - С. 34-41. 4. Шишов С. Е. Понятие компетенции в контексте качества образования / С. Е. Шишов // Стандарты и мониторинг в образовании - 1999 - № 2. - С. 30-34. 5. Шкіль М. І. Реформування вищої педагогічної освіти / М. І. Шкіль // Освіта і управління. - 1997. - № 1. - С. 39-44.

\section{САМОСТІЙНА РОБОТА СТУДЕНТІВ МУЗИЧНО-ПЕДАГОГІЧНИХ ФАКУЛЬТЕТІВ НАД АНАЛІЗОМ ХОРОВИХ ТВОРІВ НА ЗАНЯТТЯХ ІЗ ХОРОВОГО ДИРИГУВАННЯ}

Кокарева Е. О. Самостійна робота студентів музично-педагогічних факультетів над аналізом хорових творів на заняттях із хорового диригування.

У статті розглянуто проблему самостійної роботи студентів музично-педагогічного факультету над аналізом хорових творів, здійснено пошук ефективних шляхів іiі розв'язання, розкрито специфіку роботи над нотним матеріалом на заняттях з хорового диригування.

Ключові слова: самостійна робота студентів, аналіз хорових творів, нотний матеріал, хорове диригування.

Кокарева Э. А. Самостоятельная работа студентов музыкально-педагогических факультетов над анализом хоровых произведений на занятиях по хоровому дирижированию.

В статье рассматривается проблема самостоятельной работы студентов музыкальнопедагогического факультета над анализом хоровых призведений, осуществлен поиск эффективных путей ее решения, раскрыта специфика работы над нотным материалом на занятиях по хоровому дирижированию.

Ключевые слова: самостоятельная работа студентов, анализ хоровых призведений, нотный материал, хоровое дирижирование.

Kokareva E. A. Individual work of students of music\&pedagogical departments at the analysis of choral works in the classroom for choral conducting.

The article deals with the problem of independent work of students of music and pedagogical department on the analysis of choral works; makes the search of effective ways of its decision; discloses specifics of the musical material in classes on choral conducting.

Key words: students' individual work, analysis of choral works, musical material, choral conducting.

У сучасній системі вищої освіти одним із найважливіших питань вдосконалення навчального процесу є пошук шляхів формування творчої самостійності студентів. Значну роль у розв'язанні поставленого питання відіграє самостійна робота студентів музично-педагогічних факультетів на заняттях із хорового диригування. Повноцінна професійна діяльність учителя музики неможлива без достатньої диригентсько-хорової підготовки, що передбачає як найважливіший аспект його постійну самостійну роботу та творче самовдосконалення.

Формування навичок самостійної діяльності студентів - одне з актуальних завдань сучасної освіти, а розвиток навичок самостійної роботи над нотним матеріалом, зокрема, хоровим твором, $\epsilon$ однією 3 обов'язкових умов успішного навчання студентів музично-педагогічних факультетів. У розв'язанні цієї проблеми значна роль відводиться формуванню в них умінь і навичок самостійного мислення i практичного застосування знань. Необхідно навчити студентів самостійно набувати знання з різних джерел інформації, оволодіти якомога більшою кількістю різноманітних видів і прийомів самостійної роботи.

Дисципліна «Хорове диригування» вважається однією із профілюючих на музичнопедагогічних факультетах (О. Апраксіна, Н. Гродзенська, Л. Хлєбнікова, В. Шацька та ін.) та 